\title{
Planning and Development: Social Capital and Promoting Mental Health
}

\author{
Nour Mohammad Yaghoubi ${ }^{1}$, Masoumeh Zare Kaseb ${ }^{2}$, Sayed Moslem Sayedalhosseini ${ }^{3}$, Jamshid Moloudi ${ }^{1}$ \& \\ Homayoon Nori $^{2}$ \\ ${ }^{1}$ University of Sistan and Baluchestan, Iran \\ ${ }^{2}$ Islamic Azad University, Zahedan branch, Zahedan, Iran \\ ${ }^{3}$ Department of Urban Planning and Design, Mashhad branch, Islamic Azad University, Mashhad, Iran \\ Correspondence: Jamshid Moloudi, University of Sistan and Baluchestan, Iran. E-mail: \\ esfehani.mohamad3@gmail.com
}

Received: June 15, 2016

Accepted: July 4, $2016 \quad$ Online Published: August 15, 2016

doi:10.5539/mas.v10n12p146

URL: http://dx.doi.org/10.5539/mas.v10n12p146

\begin{abstract}
During the planning and development of a country, social capital along with natural, human and physical capitals is considered as input and output of development. In underdeveloped countries, social capital is called as missing link development. According to the impact of this factor on varicose aspects of human life and more importantly on Mental Health, the present study attempted to identify the main factor of Mental Health and how to increase it by Social Capital and its dimensions (Cognitive, Relative and Structural Capitals). Present study researchers have used the Social capital and Mental Health theories, application survey and questionnaire. In present research the sample size consists of 264 employees (59 women and 205 men) that were selected at random from 243 small and medium enterprises located in Science and Technology Park. Data analysis was carried out by using the statistical program packages SPSS 17.0, AMOS SPSS 16.0.1 and LISREL 8.54. Results of the present study were illustrated that there is significant relationship between Social capital and its dimensions and Mental health in the present companies $(\mathrm{p}<0 / 01)$. The results of Enter Regression showed that predictor variables significantly (cognitive, relative and structural capital) have determined $47.7 \%$ of the variance of Mental Health together. Also the result of LISREL statistical software was illustrated that the data of present study involve significant goodness of fit. Also the interesting results were obtained from Regression analysis and Factor Analysis to predict Social capital and its dimensions on the mental health that will watch in the present study.
\end{abstract}

Keywords: social capital, cognitive capital, planning and development, structural capital and mental health

\section{Introduction}

Today, due to technological advances and its direction impact on the quality of human life, the health problem and influencing factors on it have been particularly important. So that the common goal of development in the local level is improving quality of life and the most important of all is Mental Health. According to Health World Organization definition, Mental Health is defined: ability to balance and harmony with others, changing and reforming the individual and social environments, resolve conflicts and personal desires logically, fairly and appropriately. Also, Nowadays, a large part of disease forms (mental or physical) in the developing countries are related to social factors and models strongly (World Health Organization [WHO], 2001). The effects of these factors turn out to be long term. The problems are as poverty, failure in education, living in inappropriate physical environment, high levels of insecurity in society (e.g., violence and accidents) and also the factors as negative life events as separation from parents, loss of job, forced migration that is impact on mental health of people (Harphan, 2004).

The concept of social capital is expressed in the more development topics and attention to social capital and its role in mental health of people in the different levels by many scholars. Patel was believed that the role of social factors in mental health is clearly. Lynch \& Kaplan (1997) introduced social capital as capital accumulation and networks that create social correlation, social commitment and consequently, a kind of self-esteem and health in people (Lynch \& Kaplan, 1997). Rose (2000) was believed that social capital is obtained only by membership in institutions and social capital networks and it provides emotional and mental supports for mental health 
promotion (Rose, 2000). Putnam (1995) was known social capital composed of components as networks, norms and trust (Putnam, 1995). Wilkinson (1999) was told that the factors as injustices, frustrations and disrespects are caused by social factors that endanger the health of people (Wilkinson, 1999). The findings of researches and studies of World Health Organization (WHO) were illustrated that today, more than 450 million people in the word have psychological problems, while the researchers have predicted this figure more and more will be up to twenty years (WHO, 2004). The overall and main aim of present study is studied the relationship between social capital and it dimensions and mental health in 243 small and medium enterprises located in Science and Technology Park in East Azerbaijan-Iran in 2011.

\section{Literature Review}

In the mid-19th century, William Sweetzer was the first to clearly define the term "mental hygiene", which can be seen as the precursor to contemporary approaches to work on promoting positive mental health (Johns Hopkins University, 2007). Isaac Ray, one of thirteen founders of the American Psychiatric Association, further defined mental hygiene as an art to preserve the mind against incidents and influences which would inhibit or destroy its energy, quality or development (Johns Hopkins University, 2007). At the beginning of the 20th century, Clifford Beers founded the National Committee for Mental Hygiene and opened the first outpatient mental health clinic in the United States (Johns Hopkins University, 2007; Clifford Beers Clinic, 2006). There are different types of mental health problems, some of which are common, such as depression and anxiety disorders, and some not so common, such as schizophrenia and bipolar disorder. However, all mental health problems cause a lot of disability to the sufferer (Kitchener \& Jorm, 2002).

\subsection{Mental Health}

Describes either a level of cognitive or emotional well-being or an absence of a mental disorder Princeton University (Princeton University, 2007). From perspectives of the discipline of positive psychology or holism mental health may include an individual's ability to enjoy life and procure a balance between life activities and efforts to achieve psychological resilience (About.com, 2006). Mental health is an expression of our emotions and signifies a successful adaptation to a range of demands. The World Health Organization defines mental health as "a state of well-being in which the individual realizes his or her own abilities, can cope with the normal stresses of life, can work productively and fruitfully, and is able to make a contribution to his or her community" (WHO, 2005). It was previously stated that there was no one "official" definition of mental health. Cultural differences, subjective assessments, and competing professional theories all affect how "mental health" is defined (World Health Report, 2001). Most recently, the field of Global Mental Health has emerged, which has been defined as 'the area of study, research and practice that places a priority on improving mental health and achieving equity in mental health for all people worldwide (Patel \& Prince, 2010).

\subsection{Mental Wellbeing}

Mental health can be seen as a continuum, where an individual's mental health may have many different possible values (Keyes, 2002). Mental wellness is generally viewed as a positive attribute, such that a person can reach enhanced levels of mental health, even if they do not have any diagnosable mental health condition. This definition of mental health highlights emotional well-being, the capacity to live a full and creative life, and the flexibility to deal with life's inevitable challenges. Many therapeutic systems and self-help books offer methods and philosophies espousing strategies and techniques vaunted as effective for further improving the mental wellness of otherwise healthy people. Positive psychology is increasingly prominent in mental health.

A holistic model of mental health generally includes concepts based upon anthropological, educational, psychological, religious and sociological perspectives, as well as theoretical perspectives from personality, social, clinical, health and developmental psychology (Witmer \& Sweeny, 1992; Hattie, Myers, \& Sweeney, 2004).

An example of a wellness model includes one developed by Myers, Sweeney and Witmer. It includes five life tasks - essence or spirituality, work and leisure, friendship, love and self-direction - and twelve sub tasks - sense of worth, sense of control, realistic beliefs, emotional awareness and coping, problem solving and creativity, sense of humor, nutrition, exercise, self care, stress management, gender identity, and cultural identity — which are identified as characteristics of healthy functioning and a major component of wellness. The components provide a means of responding to the circumstances of life in a manner that promotes healthy functioning. Most of the US Population is not educated on Mental Health (Myers, Sweeny, \& Witmer, 2000).

\subsection{Lack of a Mental Disorder}

Mental health can also be defined as an absence of a major mental health condition (for example, one of the diagnoses in the Diagnostic and Statistical Manual of Mental Disorders) though recent evidence stemming from 
positive psychology (see above) suggests mental health is more than the mere absence of a mental disorder or illness. Quite simply, mental health refers to a person's health of the mind (Kozier, 2008). Therefore the impact of social, cultural, physical and education can all affect someone's mental health (Kitchener \& Jorm, 2002).

\subsection{Social Capital}

Social Capital is a sociological concept, which refers to connections within and between social networks. Though there are a variety of related definitions, which have been described as "something of a cure-all" (Portes, 1998) for the problems of modern society, they tend to share the core idea "that social networks have value. Just as a screwdriver (physical capital) or a college education (human capital) can increase productivity (both individual and collective), so do social contacts affect the productivity of individuals and groups" (Putnam, 2000).

While various aspects of the concept have been approached by all social science fields, some trace the modern usage of the term to Jane Jacobs in the 1960s. However, she did not explicitly define a term social capital but used it in an article with a reference to the value of networks. Political scientist Robert Salisbury advanced the term as a critical component of interest group formation in his 1969 article "An Exchange Theory of Interest Groups" in the Midwest Journal of Political Science. Sociologist Pierre Bourdieu used the term in 1983 in his Outline of a Theory of Practice, and clarified the term some years later in contrast to cultural, economic, and symbolic capital. Sociologists James Coleman, Barry Wellman and Scot Wortley adopted Glenn Loury's 1977 definition in developing and popularizing the concept (Coleman, 1988). In the late 1990s the concept gained popularity, serving as the focus of a World Bank research program and the subject of several mainstream books, including Robert Putnam's Bowling Alone and Putnam and Lewis Feldstein's Better Together.

The power of 'community governance' has been stressed by many philosophers from Antiquity to the 18th century, from Aristotle to Thomas Aquinas and Edmund Burke (Bowles \& Gintis, 2002).This vision was strongly criticized at the end of the 18th century, with the development of the idea of Homo Economics and subsequently with 'rational choice theory'. Such a set of theories became dominant in the last centuries, but many thinkers questioned the complicated relationship between 'modern society' and the importance of 'old institutions', in particular family and traditional communities (Ferragina, 2010). The debate community versus modernization of society and individualism has been the most discussed topic among the fathers of sociology (Tonnies, 1887; Durkheim, 1893; Simmel, 1905; Weber, 1946). They were convinced that industrialization and urbanization were transforming social relationship in an irreversible way. They observed a breakdown of traditional bonds and the progressive development of anomie and alienation in society (Wilmott, 1986). After Tonnie's and Weber works, reflection on social links in modern society continued with interesting contributions in the 1950s and in the 1960s, in particular 'The Mass Society Theory' (Bell, 1962; Nisbet, 1969; Stein, 1960; Whyte, 1956). They proposed themes similar to those of the founding fathers, with a more pessimistic emphasis on the development of society (Ferragina, 2010). In the words of Stein (1960):"The price for maintaining a society that encourages cultural differentiation and experimentation is unquestionably the acceptance of a certain amount of disorganization on both the individual and social level." All these reflections contributed remarkably to the development of the social capital concept in the following decades. The appearance of the modern social capital conceptualization is a new way to look at this debate, keeping together the importance of community to build generalized trust and the same time, the importance of individual free choice, in order to create a more cohesive society (Ferragina, 2010). It is for this reason that social capital generated so much interest in the academic and political world (Rose, 2000).

Though Bourdieu might agree with Coleman that social capital in the abstract is a neutral resource, his work tends to show how it can be used practically to produce or reproduce inequality, demonstrating for instance how people gain access to powerful positions through the direct and indirect employment of social connections. Robert Putnam has used the concept in a much more positive light: though he was at first careful to argue that social capital was a neutral term, stating "whether or not [the] shared are praiseworthy is, of course, entirely another matter" (Foley \& Edwards, 1997) his work on American society tends to frame social capital as a producer of "civic engagement" and also a broad societal measure of communal health. He also transforms social capital from a resource possessed by individuals to an attribute of collectives, focusing on norms and trust as producers of social capital to the exclusion of networks.

Nahapiet \& Ghoshal (1998) were explained that there are three elements that are proposed as encompassing social capital, as follow: cognitive capital, relative capital and structural capital. The cognitive aspect of social capital can be description as share of language and stories that there are in organization and society. The relative capital refers to trust, norms and religions, obligations and exceptions and identity that exciting or current in organization. The structural aspect of social capital can be defined as network relation between people, formulated of network and adopt an organization. These three elements of Social capital are portrayed in Table 1. 
Table 1. Elements of Social Capital (Nahapiet \& Ghoshal, 1998)

\begin{tabular}{|c|c|c|}
\hline \multirow{9}{*}{ 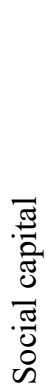 } & \multirow{2}{*}{ Cognitive Capital } & Share of Stories \\
\hline & & Share of Language \\
\hline & \multirow{4}{*}{ Relative Capital } & Trust \\
\hline & & Norms and Religions \\
\hline & & Obligations \& Exceptions \\
\hline & & Identity \\
\hline & \multirow{3}{*}{ Structural Capital } & Network relation between people \\
\hline & & Formulated of Network \\
\hline & & Appropriate Organization \\
\hline
\end{tabular}

\subsection{Social Capital a New Concept from an Old Idea}

The modern emergence of social capital concept renewed the academic interest for an old debate in social science: the relationship between trust, social networks and the development of modern industrial society. Social Capital Theory gained importance through the integration of classical sociological theory with the description of an intangible form of capital. In this way the classical definition of capital has been overcome allowing researchers to tackle issues in a new manner (Ferragina, 2010). Through the social capital concept researchers have tried to propose a synthesis between the value contained in the communitarian approaches and individualism professed by the 'rational choice theory.' Social capital can only be generated collectively thanks to the presence of communities and social networks, but individuals and groups can use it at the same time. Individuals can exploit social capital of their networks to achieve private objectives and groups can use it to enforce a certain set of norms or behaviors. In this sense, social capital is generated collectively but it can also be used individually, bridging the dichotomized approach 'communitarianism' versus 'individualism' (Ferragina, 2010).

\subsection{Effects of Social Capital on Health and Mental Health}

A growing body of research has found that the presence of social capital through social networks and communities has a protective quality on health. Social capital affects health risk behavior in the sense that individuals who are embedded in a network or community rich in support, social trust, information, and norms, have resources that help achieve health goals (Lin, 1999). For example, a person who is sick with cancer may receive information, money, or moral support he or she needs to endure treatment and recover. Social capital also encourages social trust and membership. These factors can discourage individuals from engaging in risky health behaviors such as smoking and binge drinking (Bolin, Lindgren, Lindstrom, \& Nystedt, 2003)

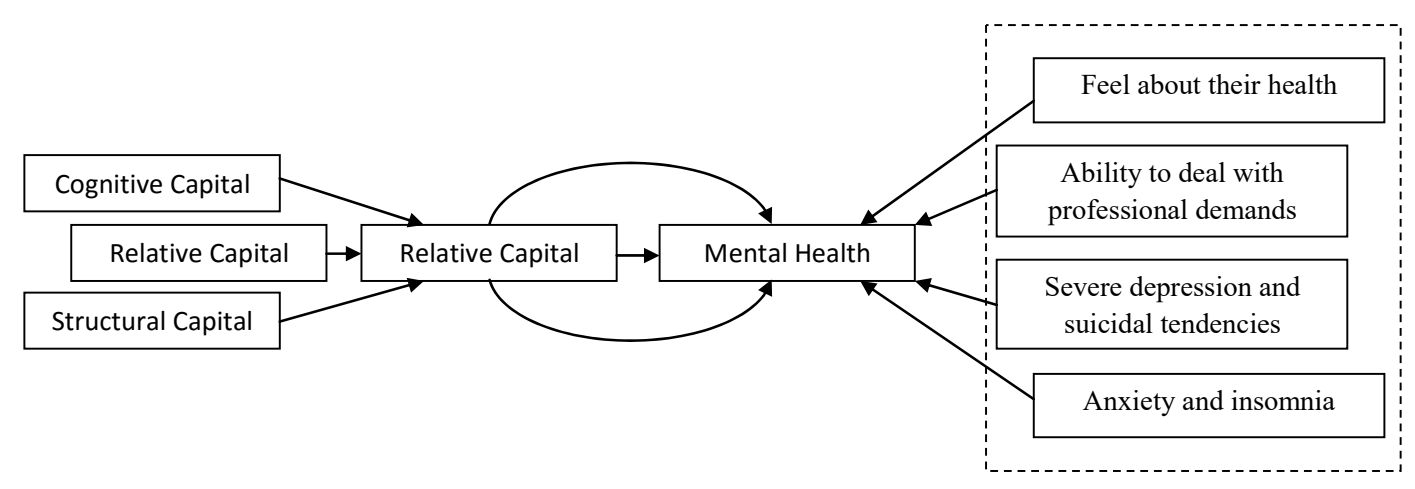

Figure 1. Conceptual Framework

Inversely, a lack of social capital can impair health. For example, results from a survey given to 13-18 year old students in Sweden showed that low social capital and low social trust are associated with higher rates of psychosomatic symptoms, musculoskeletal pain, and depression (Aslund, Starrin, \& Nilsson, 2010). Additionally, negative social capital can detract from health. Although there are only a few studies that assess social capital in criminalized populations, there is information that suggests that social capital does have a negative effect in broken communities. Deviant behavior is encouraged by deviant peers via favorable definitions and learning opportunities provided by network-based norms. However in these same communities, an adjustment of norms 
(i.e., deviant peers being replaced by positive role models) can pose a positive effect.

Lee (2004) was studies about Social Support Buffering of Acculturation Stress: A Study of Mental Health Symptoms among Korean International Students. The result of theirs study was illustrated that Social Support has positive effect on Mental Health and also a student who has gained high score of social support examination, has obtained low score in mental and Acculturation stress examination. This result was explained that there is vice versa relationship between these two items (Lee et al., 2004). Thompson (2002) was studied about The Social and Cultural Context of the Mental Health of Filipinas in Queensland. They were focused on two dimensions of social and emotional support and were perused the relationship between these dimensions and mental health among immigrants of Filipinas. The results of this study were showed that the immigrants of Filipinas involved with mental and emotional problems when they traveled from popularity society to individualist society. Also, the other result of this study was indicated that social support and common communications (As: cultural identity, language and common interests) can have main role on mental health and its contingency (Thompson et al., 2002). Silvera \& Allebech (2001) were studies about Migration, Aging and Mental Health: An Ethnographic Study on Perceptions of Life Satisfaction, Anxiety and Depression in Older Somali Men in East London.

The aim of them was studied the relationship between social capital and mental health among immigrants of Somali in East London. The findings of this survey the factors as low family support and specially solitude, limited and inappropriately access to public services, inability in return to home and social scorn cause to incapacitate the mental health of immigrants. Also, inappropriately access to general and public services, consternation in social supports, ruining the relatives and friendship and geographic distance and kinfolk have the important role on mental health (Silvera \& Allebech, 2001). Schwirian (1993) was studied about Neighboring, Residential Satisfaction and Psychological Wellbeing Inurbane Elders and the role of social capital on mental health of immigrants. The results of this study was indicated that neighborhood as a social sponsor is important for immigrants of mental health. He used two systematic and liner development models in his research that basic of these two models are having nice friends, acquaintance and neighborhoods in the city that is effective to mental health of immigrants. Also, in this research people who are high social mobility, income and enjoyed from social, financial and mental supports have had better mental health (Schwirian, 1993). Desouza (2005) in his research about Migration and Mental Health was emphasized to the role of factors as economic, social and education situation in mental health (Desouza, 2005). According to the letireture review of present study, the cancepual framework of this article is following (see to Tab. 1):

\section{Research Questions}

Considering to high content, can be said that the main questions of present study are following:

Is there any significant correlation between dimensions of Social Capital and Mental Health?

What is regression equation of Mental Health on dimensions of Social Capital?

Is there acceptable goodness of fit in exploratory and structural equation modeling in present study?

\section{Methodology}

East Azerbaijan Science \& Technology Park (EASTP) was founded in the year 2003. It is located in Tabriz, Capital of East Azerbaijan province, Islamic Republic of Iran. On June 3rd 2003 East Park became a member of IASP. IASP (International Association of Science Parks) established in 1984- is located in Spain. It consist members from 73 different countries from all over the word .East Azerbaijan Science \& Technology Park is now a full member of IASP (2008). Data for this study were collected by the questionnaires of Social Capital and Mental Health of 243 Medium and Small Companies of EASTP of East Azerbaijan-Iran. Social capital questionnaire was designed by Nahapiet \& Ghoshal (1998). It contains 35 items and it has 3 dimensions namely: cognitive capital, relative capital and structural capital. Its reliability of this questionnaire was reported 0.87 . Mental Health was designed by Goldberg \& Hillier (1979).

It contains 28 items and it has 4 dimensions namely: (Feel about their health, Anxiety and insomnia, Ability to deal with professional demands and Severe depression and suicidal tendencies). Its reliability was reported 0.826 . The questionnaires used 5 point Likert scales ( 1 represent strongly disagree and 5 represent strongly agree) to measure the construct. Data analysis was carried out by using the statistical program packages SPSS 17.0, Amos 16.0.1 and Lisrel 8.54. Among the respondent, $77.6 \%$ was male and $22.4 \%$ female.

\section{Result}

The Pearson correlation for the study variables is given in Table 2. Organizational Citizenship Behaviors and its 
dimensions of were correlated with Human resource productivity. Dimensions of OCB and OCB were significantly related to Human resource management and its dimensions. The results of Table 2 illustrates that there are positive relationship between all items.

The Pearson correlation for the study variables is given in Table 2. Social Capital and its dimensions of were correlated with Mental Health. Social Capital and its Dimensions were significantly related to Mental Health and its dimensions. The results of Table 2 illustrates that there are positive relationship between all items. And also the Table 3 is illustrating Model summery of regression of Social Capital and Mental Health.

Table 2. Shows Pearson correlation coefficient between Social Capital and Mental Health and theirs dimensions and $(\mathrm{n}=264)$

\begin{tabular}{lrrrrr}
\hline Correlations & \multicolumn{1}{l}{$\begin{array}{l}\text { Feel about } \\
\text { their health }\end{array}$} & $\begin{array}{r}\text { Anxiety and } \\
\text { insomnia }\end{array}$ & $\begin{array}{r}\text { Ability to deal with } \\
\text { professional demands }\end{array}$ & $\begin{array}{r}\text { Severe depression and } \\
\text { suicidal tendencies }\end{array}$ & $\begin{array}{r}\text { Mental } \\
\text { Health }\end{array}$ \\
\hline Cognitive Capital & $.590^{* *}$ & $.671^{* *}$ & $.436^{* *}$ & $.599^{* *}$ & $.640^{* *}$ \\
Relative Capital & $.658^{* *}$ & $.676^{* *}$ & $.289^{* *}$ & $.674^{* *}$ & $.660^{* *}$ \\
Structural Capital & $.652^{* *}$ & $.672^{* *}$ & $.330^{* *}$ & $.664^{* *}$ & $.662^{* *}$ \\
Social Capital & $.664^{* *}$ & $.708^{* *}$ & $.376^{* *}$ & $.676^{* *}$ & $.687^{* *}$ \\
\hline
\end{tabular}

Note. ${ }^{* *}$. Correlation is significant at the 0.01 level (2-tailed).

Table 3. Model summery of regression of Social Capital and Mental Health $(n=264)$

\begin{tabular}{|c|c|c|c|}
\hline $\mathrm{R}$ & R Square & Adjusted R Square & Std. Error of the Estimate \\
\hline $.690^{\mathrm{a}}$ & .477 & .471 & .46994 \\
\hline \multicolumn{4}{|c|}{ a. Predictors: (Constant), Cognitive, Relative and Structural Capital } \\
\hline
\end{tabular}

As seen, the significant predictor (Cognitive, Relative and Structural Capitals) has determined $47.7 \%$ of the variance of Mental Health.

As, it was expected to predict creating depending on Social Capital and its dimensions, P-variable regression was applied, Social Capital as predictor variable and Mental Health as depended variable were analyzed.

Data of table 4 and 5 illustrated that Social Capital and its dimensions predicts on the Mental Health. Eventually each increase or decrease in dimensions of Social Capital reason same change in Mental Health.

Table 4. ANOVA of Social Capital and its dimension on the Mental Health $(\mathrm{n}=264)$

\begin{tabular}{|c|c|c|c|c|c|}
\hline Model & Sum of & $\mathrm{df}$ & Mean Square & & Sig. \\
\hline Regression & 54.689 & 3 & 18.230 & & $5.000^{\mathrm{a}}$ \\
\hline Residual & 60.069 & 272 & .221 & - & - \\
\hline Total & 114.758 & 275 & & - & - \\
\hline
\end{tabular}

Note. a. Predictors: (Constant), Cognitive, Relative and Structural Capitals; b. Dependent Variable: Mental Health.

Table 5. Regression analysis to predict Social Capital and its dimension on the Mental Health $(n=264)$

\begin{tabular}{|c|c|c|c|c|c|}
\hline Predictor Variable & & Std. & r Beta & & Sig. \\
\hline (Constant) & 1.088 & 8.135 & - & 8.037 & 7.000 \\
\hline Cognitive Capital & .173 & .079 & .215 & 2.19 & 4.029 \\
\hline Relative Capital & .345 & .092 & .334 & 3.741 & 1.000 \\
\hline Structural Capital & .160 & .108 & .179 & 1.477 & 7.141 \\
\hline
\end{tabular}


As seen, Relative Capital has satisfied the entrance criterion of the regression and entered as a first important predictor $(B e t a=0.334)$. In second step Cognitive Capital has satisfied the entrance criterion of the regression and entered as a second important predictor $(B e t a=0.215)$. But other dimension of Social Capital namely Structural Capital could not satisfy the entrance criterion of the regression, then regression equation of the regression of Mental Health on Social Capital and its dimensions is as fallow: Mental Health $=0.334$ (Relative Capital) +0.215 (Cognitive Capital)

In accordance with Byrne (1998), a ratio of $X 2$ to df of less than 3 was generally considered an indicator of good model fit, and a ratio of less than 5 was considered acceptable. An adjusted goodness-of-fit index (AGFI) of more than 0.90, a root-mean-square error of approximation (RMSEA) of less than 0.08, and Root Mean Square Residual (RMR) of less than 0.045 and a normal fit index (NFI), Non-Normed Fit Index (NNFI), Comparative Fit Index (CFI) and Incremental Fit Index (IFI) of more than 0.90 were considered indicators of "good fit" Given their complementary features all four indexes were used to evaluate the path model. In this model we use abbreviation of both of criteria's dimensions ( $\mathrm{SS}=$ Share of Stories, $\mathrm{SL}=$ Share of Language, $\mathrm{TR}=$ Trust, NR = Norms and Religions, $\mathrm{OE}=$ Obligations \& Exceptions, ID $=$ Identity, $\mathrm{NRB}=$ Network relation between people, $\mathrm{FN}=$ Formulated of Network, $\mathrm{AO}=$ Appropriate Organization, $\mathrm{CON}=$ Cognitive Capital, REL $=$ Relative Capital, STR $=$ Structural Capital, $\mathrm{Q}=$ Feel about their health, $\mathrm{W}=$ Anxiety and insomnia, E = Ability to deal with professional demands and $\mathrm{R}=$ Severe depression and suicidal tendencies).

Table 6. Structural Equation Modeling (Estimate state and T-value) of dimensions and elements of Social capital

\begin{tabular}{|c|c|c|c|c|c|c|}
\hline \multirow{10}{*}{ 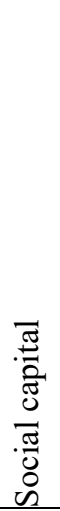 } & $\begin{array}{l}\text { Estimate } \\
\text { state }\end{array}$ & T-value & $\begin{array}{l}\text { Dimensions of Social } \\
\text { Capital }\end{array}$ & $\begin{array}{l}\text { Estimate } \\
\text { state }\end{array}$ & T-value & $\begin{array}{l}\text { Elements of dimensions of } \\
\text { social capital }\end{array}$ \\
\hline & \multirow{3}{*}{1.06} & \multirow{3}{*}{3.57} & \multirow{3}{*}{ Cognitive Capital } & 0.61 & 3.42 & Share of Stories \\
\hline & & & & 0.75 & 3.51 & Share of Language \\
\hline & & & & 0.70 & 4.26 & Trust \\
\hline & \multirow{3}{*}{1.08} & \multirow{3}{*}{4.19} & \multirow{3}{*}{ Relative Capital } & 0.36 & 2.00 & Norms and Religions \\
\hline & & & & 0.71 & 4.32 & Obligations \& Exceptions \\
\hline & & & & 0.29 & 2.25 & Identity \\
\hline & \multirow{3}{*}{1.06} & \multirow{3}{*}{4.46} & \multirow{3}{*}{ Structural Capital } & 0.73 & 5.12 & $\begin{array}{l}\text { Network relation between } \\
\text { people }\end{array}$ \\
\hline & & & & 0.62 & 4.26 & Formulated of Network \\
\hline & & & & 0.63 & 4.38 & Appropriate Organization \\
\hline
\end{tabular}

Note. Chi-square $=39.46 \mathrm{df}=24$ P-value $=0.01145$ RMSEA $=0.074$

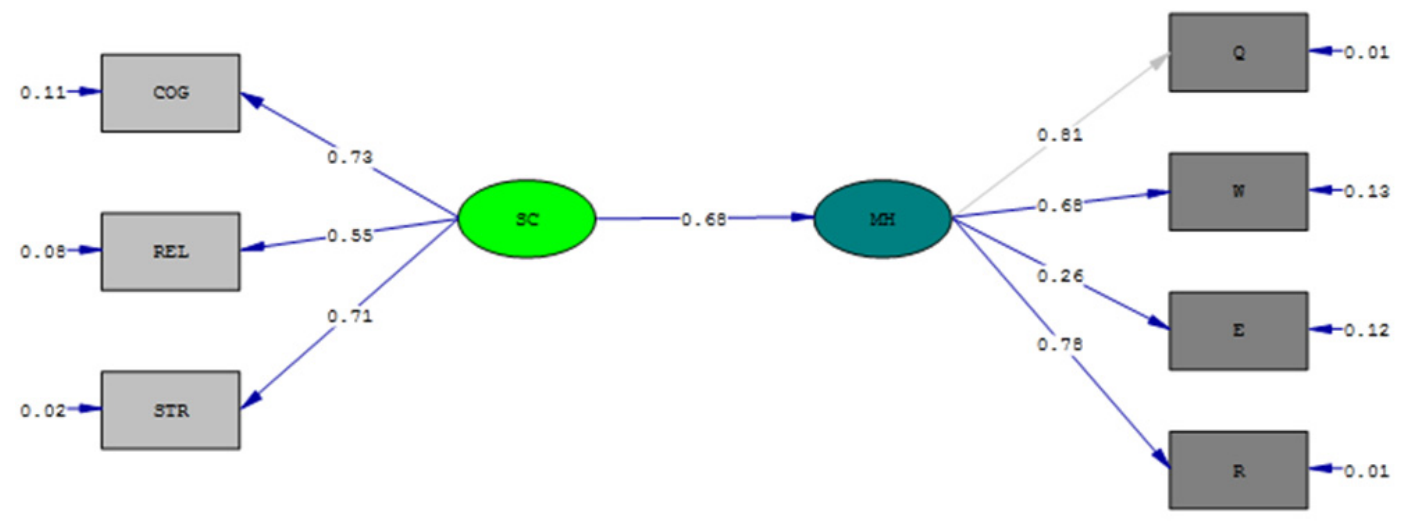

Chi-Square=38.75, $d f=13, p-v a l u e=0.01473$, RMSEA=0.068

Figure 2. Structural Equation Modeling (Estimate State) of Social Capital and Mental Health 


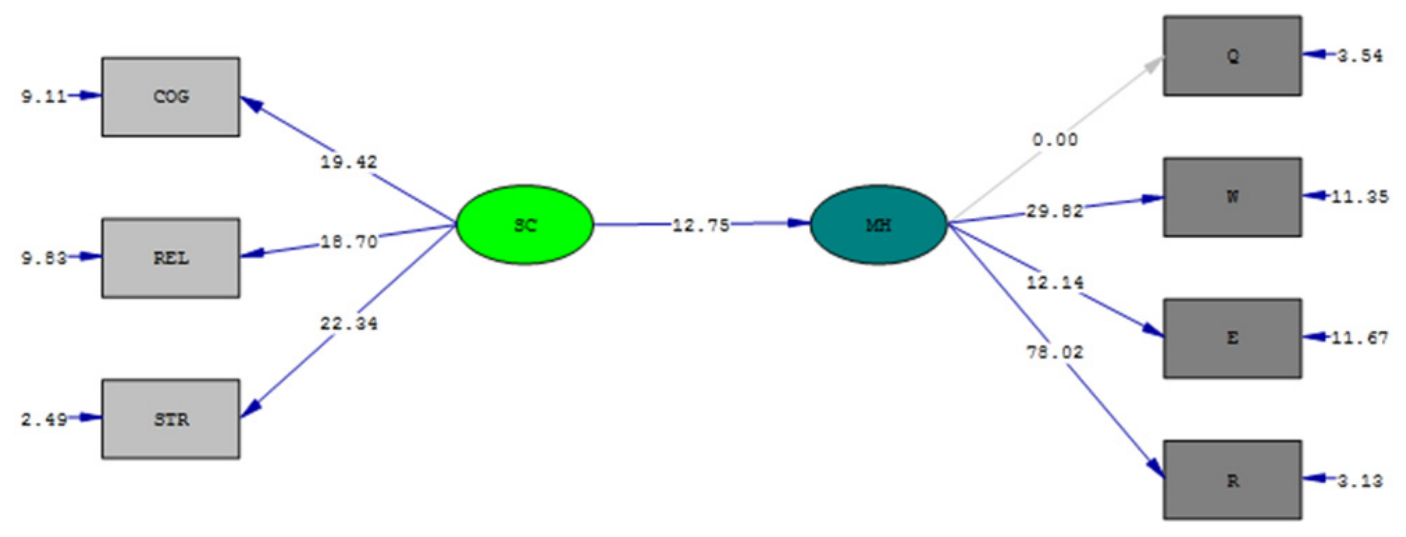

Chi-Square=38.75, df $=13, \mathrm{P}-\mathrm{value}=0.01473, \mathrm{RMSEA}=0.068$

Figure 3. Structural Equation Modeling (T-Value) of Social Capital and Mental Health

Table 7. Model summary of Goodness of fit statistics $(n=264)$

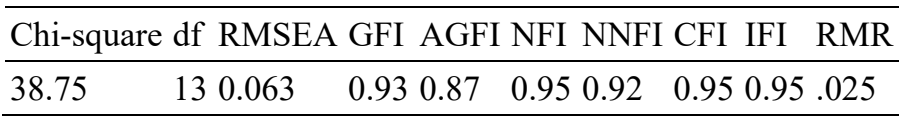

The data of Table 6 can be said that the model of social capital for present study is fitness and also it showed that the Social Capital questionnaire has acceptable structural justifiability. Likewise, the data of Figures 2, 3 and Table 7 are illustrated that the exploratory model including all hypothesized variables provided an adequate fit $(\mathrm{x} 2=$ $38.75 ; \mathrm{df}=13 ; \mathrm{p}=0.01473$; a ratio of $\mathrm{x} 2$ to $\mathrm{df}$ of less than 3; goodness of fit index $[\mathrm{GFI}]=0.93$; adjusted goodness-of-fit index $[\mathrm{AGFI}]=0.87$; root-mean-square error of approximation $[\mathrm{RMSEA}]=0.068$ and $[\mathrm{RMR}]=$ 0.025) for the data and indicated that the relationship between Social Capital and Mental Health because of the strong direct effects of Social Capital on Mental Health. Upon figures are respectively structural equation modeling (Estimate State and T-value) and the Model summary of Goodness of fit statistics. All data of upon are in conformity with Byrne's (1998) procedures.

\section{Conclusion}

According to the literature review of the present study about Mental Health and Social Capital and findings of many researcher and scientists can be said that there is positive relationship between Mental Health and Social capital and its dimensions. The findings of present study were illustrated that among the factors of Social capital; Structural and Relative capital factors of Social Capital respectively have high correlation score than other factor (Cognitive Capital) with Mental Health. Considering to the correlation result can be explanted that Structural and Relative Capital of social capital are more important than other dimension of Social capital (in the employee's view). It means, in the workplace when these items is high, the workforces have social correlation, social commitment and consequently, a kind of self-esteem and health in people. So, totally there is positive and significant relationship between Mental Health and Social Capital according to the results of Table 2 that represents the first question of present study is acceptable. Also, according to the results of Table 3 can be concluded that significant of predictor variables namely (Cognitive, Relative and Structural Capitals) is $47.7 \%$ variance of Mental Health. The data of Table 4 was expressed that model Regression of present study is significant; because the sig. of it is less than 0.05 and even 0.01 that it means the model is significant and acceptable in 95 and even 99 percent confidence level. Also, according to results of Table 5 can be told that significantly in the Relative Capital is more than others. This means that present organizations pay attention to other dimensions of Social Capital such as this item. So, the result of Tables 3, 4 and 5 were shoed which the second question of present study is acceptable. Likewise, according to Table 6 was illustrated that the model of social capital for present study is good of fitness and also it showed that the Social Capital questionnaire has acceptable structural justifiability. Also, data of Figures 2, 3 and Table 7 were indicated that there is significant relationship between Mental Health and Social Capital strongly and Social has Capital direct effects on Mental Health. Also, can be said that present model for measuring all items is favorable. So, the result of Table 7 and Figures 2, 3 were represents that the third question of present study is acceptable. The findings of all questions of 
present study are in conformity with researches of WHO (2001), (2004), Lynch \& Kaplan (1997), Harphan (2004), Rose (2000), Wilkinson (1999), Desouza (2005), Schwirian (1993), Silvera \& Allebech (2001), Thompson (2002) and Lee (2004). Therefore, all of organizations, both generally and specially, enhance the level of Social Capital, because with higher it, social correlation, social commitment and consequently, a kind of self-esteem and health in people increase too. Thus, if the present organization and even other organizations want to achieve Health and Mental Health, they should invest as acceptable Social Capital in their organization.

\section{References}

About.com (2006). What is Mental Health? Retrieved from http://www.about.com, June 1, 2007.

Aslund, C., Starrin, B., \& Nilsson, K. (2010). Social capital in relation to depression, musculoskeletal pain, and psychosomatic symptoms: A cross-sectional study of a large population-based cohort of Swedish adolescents. BMC Public Health, (10), 715.

Barbara, K. (2008). Fundamentals of nursing: concepts process and practice. Pearson Education, 181, ISBN 9780131976535.

Barry, W., \& Wortley, S. (1990). Different Strokes from Different Folks: Community Ties and Social Support. American Journal of Sociology, (96), 558-88.

Bell, D. (1962). America as a Mass Society, in Daniel Bell (Ed.). The End of Ideology. New York: Collier Books.

Bowles, S., \& Gintis, S. (2002). Social Capital and Community Governance. The Economic Journal, (112), 419-436.

Bourdieu, P. (1983). Ökonomisches Kapital, kulturelles Kapital, soziales Kapital in Soziale Ungleichheiten (Soziale Welt, Sonderheft 2), edited by Reinhard Kreckel (pp. 249). Goettingen: Otto Schartz \& Co.

Clifford Beers Clinic. (2006). About Clifford Beers Clinic. Retrieved from CliffordBeers.org, June 1, 2007.

Coleman, J. (1988). Social Capital in the Creation of Human Capital. American Journal of Sociology Supplement, 94, S95-S120.

Desouza, R. (2005). Migration and Mental Health. Migrant News, 3(22).

Durkheim, E. (1893). De La Division du Travail. Les Caciques de Science Social.

Ferragina, E. (2010). Social Capital and equality: Tocqueville Legacy. Rethinking social capital in relation with income inequalities. The Tocqueville Review/La Revue Tocqueville, XXXI(1), 73-98.

Goldberg, D. P., \& Hillier, V. F. (1979). A scaled version of the General Health Questionnaire. Psychol Med, (9), 139-45.

Harpham, T. (2004). Urbanization and Mental Health in Developing Countries: A Research Role for Social Scientists, Public Health Professional and Social Psychiatrists. Social Science and Medicine, 39.

Hattie, J. A., Myers, J. E., \& Sweeney, T. J. (2004). A factor structure of wellness: Theory, assessment, analysis and practice. Journal of Counseling and Development, (82), 354-364.

Johns Hopkins University. (2007). Origins of Mental Health. Retrieved from JHSPH.edu, June 1, 2007.

Keyes, C. (2002). The mental health continuum: From languishing to flourishing in life. Journal of Health and Social Behaviour, 43(2), 207-222.

Kitchener, B. A., \& Jorm, A. F. (2002). Mental Health First Aide Manual (pp. 5). Centre f.o.r Mental Health Research, Canberra.

Lee, J. S. (2004). Social Support Buffering of Acculturation Stress: A Study of Mental Health Symptoms among Korean International Students. International of Intercultural Relations, 28.

Lin, N. (1999). Building a network theory of social capital. In Lin, N., Cook, K., \& Burt, R. S. (Eds.), Social capital: Theory and research, New York: Aldine de Gruyter, 3-29.

Loury, G. (1977). A Dynamic Theory of Racial Income Differences. In Wallace, P. A., \& Le Mund, A. (Eds.), Women, Minorities, and Employment Discrimination (Chapter 8). Lexington, Mass.: Lexington Books.

Lynch, J., \& Kaplan, G. (1997). Understanding How Inequality in the Distribution of Income Effect Health. Journal of Health Psychology, 2.

Myers, J. E., Sweeny, T. J., \& Witmer, J. M. (2000). The wheel of wellness counseling for wellness: A holistic model for treatment planning. Journal of Counseling and Development, (78), 251-266. 
Nahapiet, J., \& Ghoshal, S. (1998). Social capital, intellectual capital and organizational advantage. Academy of Management Review, (23), 242-266.

Nisbet, R. A. (1970). The Quest for Community. New York: Oxford University Press.

Patel, V., \& Prince, M. (2010). Global mental health-a new global health field comes of age. JAMA, 303, 1976-1977.

Portes, A. (1998). Social Capital: its origins and applications in modern sociology. Annual Review of Sociology, (24), 1-24.

Princeton University. (2007). Retrieved from http://www.princeton.edu, June 1, 2007.

Putnam, R. (1995). Democracy in America at Century end. In A. Hadenius (Ed.), Democracy Victory and Crisis. New York, Cambridge University Press.

Putnam, R. (2000). Bowling Alone: The Collapse and Revival of American Community. Simon and Schuster.

Rose, N. (2000). Community Citizenship and the Third Way. American Behavioural Scientist, (43), 1395-1411.

Rose, R. (2000). How much does Social Capital add to Individual Health? Social Science and Medicine, 51.

Schwirian, O. K., \& Schwirian, M. P. (1993). Neighboring, Residential Satisfaction and Psychological Wellbeing Inurban Elders. Journal of Community Psychology, 21.

Silvera, E., \& Allebech, P. (2001). Migration, Aging and Mental Health: An Ethnographic Study on Perceptions of Life Satisfaction, Anxiety and Depression in Older Somali Men in East London. International Journal of Social Welfare, 10.

Simmel, G. (1969). The Metropolis and Mental Life. In Richard Sennet (Eds.), Classic Essays on the Culture of Cities. New York: Appleton-Century-Crofts.

Stein, M. R. (1960). The Eclipse of Community: an Interpretation of American Studies. Princeton: Princeton University Press.

Thompson, S. (2002). The Social and Cultural Context of the Mental Health of Filipinas in Queensland. Australian and New Zeland Journal of Psychology, 36.

Tonnies, F. (1955). Community and Association. London: Rutledge and Kegan Paul.

Weber, M. (1946). The Protestant Sects and the Spirit of Capitalism. In Hans H. Gert \& Mills C. Wright (Eds.), From Max Weber. New York: Oxford University Press.

WHO. (2001). The World Health Report: Mental Health, Geneva. World Health Organization.

WHO. (2004). Promoting Mental Health: A Report of the World Health Organization. Department of Mental Health, University of Melbourne.

Whyte, W. (1956). The Organization Man. New York: Simon and Schuster.

Wilkinson, R. (1999). Income Inequality, Social Cohesion and Health. International Journal of Health Services, 29.

Wilmott, P. (1986). Social Networks, Informal Care and Public Policy. London: Policy Studies Institute.

Witmer, J. M., \& Sweeny, T. J. (1992). A holistic model for wellness and prevention over the lifespan. Journal of Counseling and Development, (71), 140-148.

World Health Organization. (2005). Promoting Mental Health: Concepts, Emerging evidence, Practice: A report of the World Health Organization, Department of Mental Health and Substance Abuse in collaboration with the Victorian Health Promotion Foundation and the University of Melbourne. World Health Organization, Geneva.

World Health Report. (2001). Mental Health: New Understanding, New Hope. World Health Organization.

\section{Copyrights}

Copyright for this article is retained by the author(s), with first publication rights granted to the journal.

This is an open-access article distributed under the terms and conditions of the Creative Commons Attribution license (http://creativecommons.org/licenses/by/4.0/). 